\title{
PENERAPAN MODEL PEMBELAJARAN SAVI BERBANTUAN MEDIA FLASHCARD UNTUK MENINGKATKAN AKTIVITAS DAN HASIL BELAJAR
}

\author{
Nur Fitriyana ${ }^{1}$, Kurnia Ningsih ${ }^{2}$, Ruqiah Ganda Putri Panjaitan ${ }^{3}$ \\ ${ }^{1,2,3}$ Program Studi Pendidikan Biologi, Fakultas Keguruan dan Ilmu Pendidikan, Universitas \\ Tanjungpura, Jalan Prof. H. Hadari Nawawi - 78115 \\ 1e-mail: nur.fitriyana201@gmail.com
}

\begin{abstract}
Abstrak
Penelitian bertujuan untuk meningkatkan aktivitas dan hasil belajar peserta didik, serta mengetahui proses pembelajaran menggunakan model pembelajaran SAVI berbantuan flashcard materi Sistem Eksresi kelas VIII SMP Negeri 5 Bunut Hulu. Subjek penelitian yaitu 22 peserta didik kelas VIII. Metode penelitian menggunakan penelitian tindakan kelas yang dilakukan dalam dua siklus. Setiap siklus terdiri dari empat tahap, yaitu perencanaan, pelaksanaan tindakan, observasi, dan refleksi. Instrumen yang digunakan meliputi lembar observasi proses pembelajaran dan aktivitas belajar, serta soal tes hasil belajar. Teknik analisis data menggunakan statistik deskriptif. Hasil penelitian menunjukkan proses pembelajaran pada siklus I sebesar $92,31 \%$ dan siklus II mencapai $100 \%$. Aktivitas belajar peserta didik pada siklus I sebesar 77,27\% dan siklus II sebesar 90,91\%. Hasil belajar menunjukkan jumlah peserta didik yang tuntas pada siklus I adalah 18 orang dengan persentase $81,82 \%$ dan siklus II adalah 21 orang dengan persentase $95,45 \%$.
\end{abstract}

Kata Kunci: model SAVI, flashcard, aktivitas, hasil belajar.

\begin{abstract}
The research aimed to improve the activities and learning outcomes of students, as well as to find out the learning process using SAVI learning models assisted by flashcard at Expression System material for Class VIII SMP Negeri 5 Bunut Hulu. The research subjects were 22 students of class VIII. The research method used classroom action research conducted in two cycles. Each cycle consists of four stages, namely planning, implementing actions, observing, and reflecting. The instruments used observation sheets of the learning process and learning activities, as well as learning achievement test questions. Data analysis techniques used descriptive statistics. The results showed that the learning process in the first cycle was $92.31 \%$ and the second cycle reached $100 \%$. Learning activities of students in the first cycle was $77.27 \%$ and the second cycle was $90.91 \%$. Learning outcomes show the number of students who completed in the first cycle was 18 people with a percentage of $81.82 \%$ and the second cycle was 21 people with a percentage of $95.45 \%$.
\end{abstract}

Keywords: SAVI model, flashcard, activity, learning outcomes.

\section{PENDAHULUAN}

Pendidikan di sekolah dapat diketahui keberhasilannya melalui tinggi rendahnya suatu kualitas pembelajaran. Pembelajaran berorientasi aktivitas 
peserta didik dapat meningkatkan kualitas pembelajaran karena peserta didik terlibat langsung dalam proses pembelajaran sehingga memperoleh sebuah pengalaman. Ada beberapa faktor yang memengaruhi aktif tidaknya peserta didik selama kegiatan pembelajaran berlangsung, yaitu: kemampuan guru; sarana dan prasarana belajar; serta lingkungan belajar (Rusman, 2016).

Proses pembelajaran melibatkan interaksi antara guru dan peserta didik. Keterlibatan peserta didik sangat diperlukan dalam belajar karena peserta didik tidak hanya sebagai penerima materi yang hanya mendengarkan saja, tetapi juga menunjukkan peran aktifnya. Semakin banyak peserta didik berperan langsung dalam kegiatan pembelajaran, maka semakin besar pula rasa keingintahuannya terhadap materi yang dipelajari (Chozaipah, 2018). Peserta didik harus berperan aktif dalam pembelajaran agar terjadinya sebuah interaksi untuk mencapai tujuan pembelajaran yang telah ditetapkan. Pembelajaran yang aktif dapat dilakukan dengan mengajak peserta didik berperan aktif dalam kegiatan pembelajaran, sehingga peserta didik memperoleh pengetahuan baru dan dapat meningkatkan pemahamannya (Rusman, 2016).

Berdasarkan hasil wawancara yang dilakukan peneliti kepada guru mata pelajaran IPA kelas VIII SMP Negeri 5 Bunut Hulu, diketahui bahwa guru menerapkan model pembelajaran berupa ceramah dan tanya jawab. Peserta didik kurang tertarik mengikuti pembelajaran dikarenakan model pembelajaran yang digunakan tidak bervariasi, sehingga hasil belajar yang didapatkan kurang maksimal (Amu, dkk., 2014). Selain penggunaan model pembelajaran yang monoton, media pembelajaran yang digunakan guru sulit untuk menjelaskan materi yang bersifat abstrak. Peran media pembelajaran selain sebagai alat bantu mengajar bagi guru juga sebagai sumber belajar bagi peserta didik dalam mendapatkan pemahaman materi yang disampaikan (Jauhari, 2018).

Berdasarkan hasil pengalaman mengajar peneliti di kelas VIII SMP Negeri 5 Bunut Hulu pada materi Sistem Pencernaan menggunakan metode ceramah dan tanya jawab, diketahui aktivitas peserta didik tergolong rendah. Jumlah peserta didik yang mengikuti pembelajaran sebanyak 22 orang. Aktivitas belajar yang diamati yaitu: peserta didik bertanya sebesar 9,1\%; peserta didik menjawab 
sebesar 9,1\%; peserta didik mencatat materi yang disampaikan sebesar 63,4\%; peserta didik membaca buku pelajaran sebesar 27,3\%; dan peserta didik berdiskusi sebesar $41 \%$. Keaktifan belajar peserta didik setidaknya $75 \%$ dari total peserta didik di kelas selama kegiatan pembelajaran berlangsung (Mulyasa dalam Wibowo, 2016).

Rendahnya hasil belajar yang diperoleh peserta didik disebabkan peserta didik merasa jenuh dan tidak tertarik terhadap pembelajaran IPA, sehingga kurangnya peserta didik yang berperan aktif dalam proses pembelajaran (Dewi dan Indrawati, 2014). Berdasarkan nilai ulangan harian mata pelajaran IPA kelas VII semester genap tahun ajaran 2017/2018 diketahui materi pembelajaran Sistem Ekskresi memiliki rata-rata nilai 64,5 dan persentase ketuntasan hanya sebesar 36,36\%. Materi tersebut belum mencapai kriteria ketuntasan minimal (KKM) yaitu 65. Hal tersebut menunjukkan bahwa pemahaman peserta didik terhadap materi masih rendah.

Model pembelajaran yang diterapkan oleh guru harus tepat sehingga peserta didik tidak merasa jenuh dan dapat menciptakan pembelajaran yang menyenangkan dengan melibatkan aktivitas fisik serta intelektual peserta didik. Peneliti mencoba menerapkan model pembelajaran SAVI (Somatik, Auditori, Visual, dan Intelektual). SAVI merupakan pembelajaran yang memanfaatkan semua alat indra yang dimiliki peserta didik untuk memperoleh pembelajaran (Ngalimun, 2016). Penggunaan model SAVI akan memanfaatkan semua alat indra peserta didik sehingga peserta didik dapat terlibat aktif dalam proses pembelajaran (Hasnah dan Dewi, 2018). Penerapan model SAVI dapat membuat peserta didik terlibat secara aktif selama proses pembelajaran, sehingga pembelajaran yang dicapai akan memberikan hasil yang baik. Kelebihan model SAVI antara lain dapat meningkatkan pemahaman peserta didik melalui penggabungan gerak fisik dengan aktivitas berpikir, serta suasana belajar-mengajar menjadi lebih menarik dan efektif (Puspitasari, dkk., 2018).

Terdapat empat unsur dalam pembelajaran SAVI, yaitu Somatis (belajar dengan bergerak dan berbuat), Auditori (belajar dengan mendengar dan berbicara), Visual (belajar dengan mengamati dan menggambarkan), dan 
Intelektual (belajar memecahkan masalah). Apabila keempat unsur SAVI digabungkan dalam suatu pembelajaran, maka kegiatan belajar yang dilakukan akan optimal. Adapun model SAVI dilakukan dalam empat tahap kegiatan, yaitu tahap persiapan, penyampaian, pelatihan, dan penampilan hasil. Hasil penelitian terdahulu terlihat bahwa penerapan model SAVI dapat meningkatkan aktivitas dan hasil belajar peserta didik SMP Aisyiyah Sungguminasa dari 33,33\% pada siklus I dan meningkat pada siklus II menjadi 93,33\% (Armawati, dkk., 2015).

Media pembelajaran digunakan untuk membantu proses pembelajaran IPA dengan menggunakan model pembelajaran SAVI. Media pembelajaran merupakan alat bantu sehingga memudahkan guru untuk memberikan pemahaman materi kepada peserta didik (Novitasari, 2017). Adapun media pembelajaran yang digunakan yaitu flalshcard. Flashcard merupakan kartu berukuran 8x12 cm yang memuat gambar dan teks yang menjelaskan suatu materi (Arsyad, 2016). Flashcard yang digunakan disesuaikan dengan besar kecilnya kelas yang dihadapi. Media flashcard menyajikan informasi singkat pada setiap kartu yang disajikan sehingga memudahkan peserta didik untuk mengingat informasi tersebut.

Penerapan model pembelajaran SAVI berbantuan media flashcard sebagai salah satu upaya untuk meningkatkan aktivitas dan hasil belajar peserta didik kelas VIII SMP Negeri 5 Bunut Hulu pada mata pelajaran IPA khususnya materi Sistem Ekskresi.

\section{METODE}

Jenis penelitian adalah penelitian tindakan kelas kolaboratif. Penelitian dilaksanakan oleh peneliti sebagai guru yang mengajar di kelas dan dibantu guru IPA di SMP Negeri 5 Bunut Hulu. Hubungan guru dan peneliti bersifat kemitraan sehingga dapat secara bersama-sama untuk memikirkan persoalan-persoalan terkait dengan penelitian tindakan kelas yang dilakukan. Subjek dalam penelitian tindakan kelas ini adalah peserta didik kelas VIII SMP Negeri 5 Bunut Hulu pada tahun ajaran 2018/2019 yang berjumlah 22 peserta didik. 
Penelitian tindakan kelas dilakukan dalam suatu siklus, setiap siklus terdiri atas empat tahap kegiatan yaitu perencanaan, pelaksanaan, pengamatan observasi, dan refleksi. Kegiatan dalam tiap siklus dapat dilihat pada Gambar 1 (Arikunto, 2013).

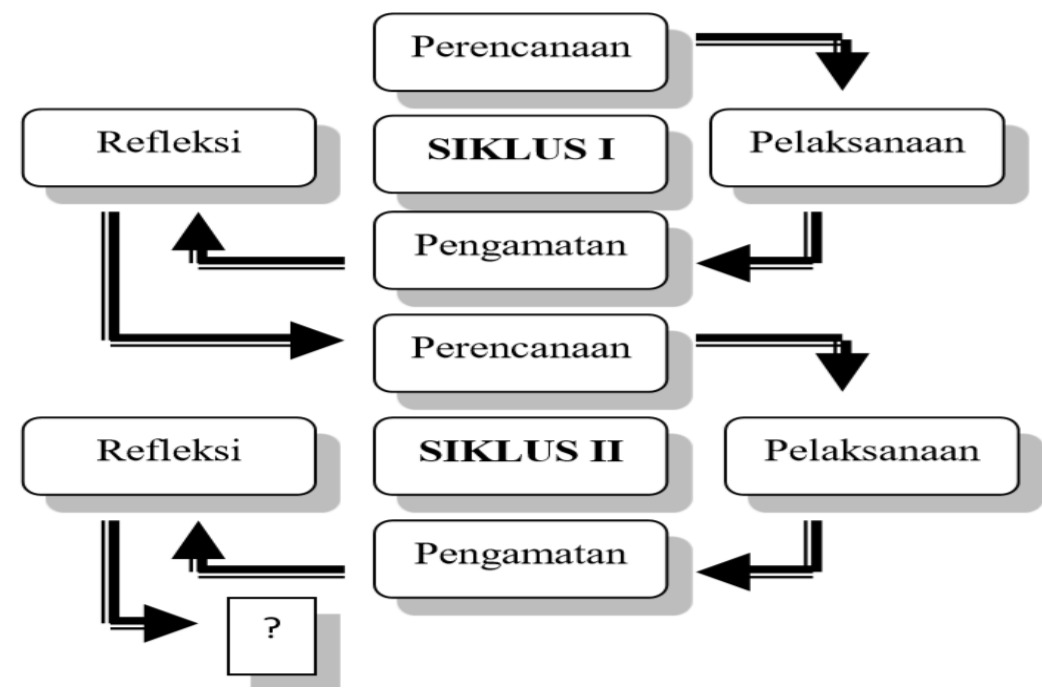

Gambar 1 Siklus Pelaksanaan PTK

Teknik pengumpulan data yang digunakan yaitu observasi yang terdiri atas observasi proses pembelajaran dan aktivitas belajar peserta didik menggunakan lembar observasi. Pengukuran hasil belajar menggunakan tes berupa soal pilihan ganda berjumlah 15 butir soal dengan 4 alternatif jawaban. Soal tes dianalisis menggunakan validitas isi dan reliabilitas KR-20. Dokumentasi berupa foto-foto dan data aktivitas belajar peserta didik.

Teknik analisis data berupa statistik deskriptif. Analisis data dilakukan dengan memberi skor. Skor yang diperoleh diubah menjadi nilai, kemudian menghitung rata-rata dan persentase. Proses pembelajaran yang diamati adalah penerapan pembelajaran IPA melalui model pembelajaran SAVI berbantuan media flashcard yang dilakukan oleh guru. Kriteria penilaian proses pembelajaran menggunaan teori dari Arikunto (2013).

Tabel 1 Kriteria Penilaian Proses Pembelajaran

\begin{tabular}{cc}
\hline Persentase (\%) & Kategori \\
\hline $75,00-100$ & Baik \\
$50,00-74,99$ & Cukup Baik \\
$25,00-45,99$ & Kurang Baik \\
$<25,00$ & Tidak Baik \\
\hline
\end{tabular}


Aktivitas belajar yang diamati meliputi memperhatikan, membaca, bertanya, menjawab, mendengarkan, berdiskusi, mencatat, mengerjakan latihan, dan bersemangat. Berdasarkan jumlah indikator yang diamati, kriteria penilaian aktivitas belajar dibagi ke dalam tiga rentang skor yang dapat dilihat pada Tabel 2 .

\section{Tabel 2 Rentang Skor Aktivitas Belajar Peserta Didik}

\begin{tabular}{cc}
\hline Skor & Kategori \\
\hline $7-9$ & Aktif \\
$4-6$ & Kurang aktif \\
$1-3$ & Tidak aktif \\
\hline
\end{tabular}

Skor aktivitas belajar peserta didik dianalisis menggunakan persentase. Hasil belajar dalam penelitian ini untuk mengukur ketuntasan belajar peserta didik. Analisis data hasil belajar mengubah skor menjadi nilai standar 100 . Indikator keberhasilan untuk mengukur keberhasilan tindakan yang dilakukan pada penelitian ini. Tindakan yang dianggap berhasil apabila sekurang-kurangnya proses pembelajaran terlaksana sebesar $85 \%$ dari 13 indikator yang diamati, aktivitas belajar sekurang-kurangnya peserta didik yang tergolong aktif sebesar $75 \%$ dari 22 peserta didik, serta sekurang-kurangnya peserta didik yang tuntas sebesar $75 \%$ dari 22 peserta didik.

\section{HASIL DAN PEMBAHASAN}

\section{Hasil}

Proses pembelajaran SAVI berbantuan flashcard pada siklus I dan II terlaksana dengan kategori baik seperti pada Gambar 2.

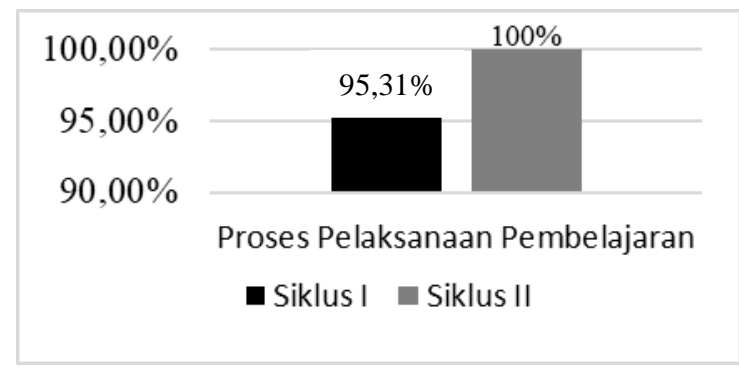

\section{Gambar 2 Persentase Proses Pembelajaran}

Persentase aktivitas belajar peserta didik yang aktif mengalami peningkatan dari siklus I sebesar 77,27\% dan meningkat pada siklus II menjadi 90,91\% dapat dilihat pada Gambar 3. 


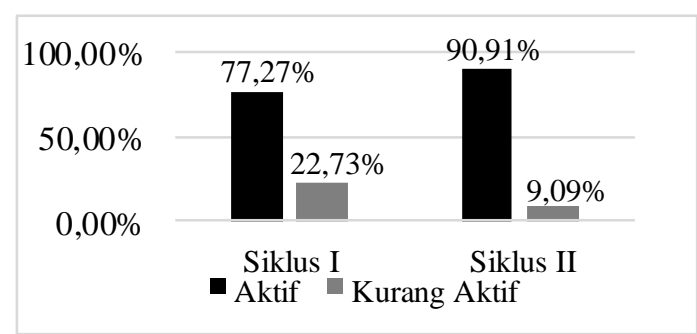

\section{Gambar 3 Persentase Aktivitas Belajar Peserta Didik}

Persentase hasil belajar peserta didik dari siklus I sebesar $81,82 \%$ dan meningkat pada siklus II menjadi 95,45\% dapat dilihat pada Gambar 4.

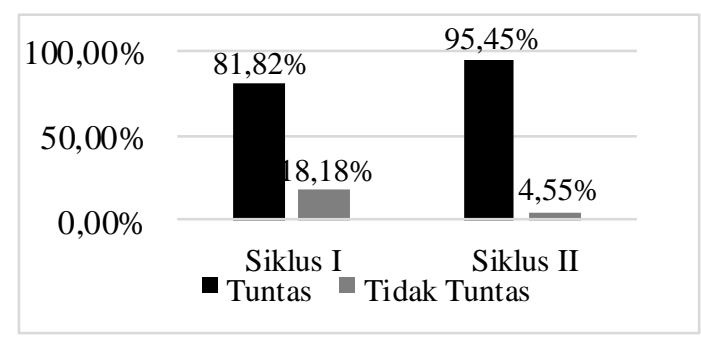

\section{Gambar 4 Persentase Hasil Belajar}

\section{Pembahasan}

\section{Proses pembelajaran model SAVI berbantuan media flashcard}

\section{Siklus I}

Tahap pertama yaitu tahap perencanaan pada siklus ini dilakukan dengan merancang instrumen pembelajaran berupa Rencana Pelaksanaan Pembelajaran (RPP) dengan menerapkan model pembelajaran SAVI, Lembar Kerja Peserta Didik (LKPD), soal tes, mempersiapkan lembar observasi untuk mengamati proses pembelajaran dan aktivitas belajar peserta didik, serta mempersiapkan media flashcard yang telah divalidasi agar layak digunakan. Tahap selanjutnya yaitu pelaksanaan tindakan. Pelaksanaan tindakan siklus I dilaksanakan pada Kamis, 2 Mei 2019 pukul 07.00-09.00 WIB dengan alokasi waktu 3x40 menit. Materi yang diajarkan tentang organ-organ penyusun sistem ekskresi, struktur, dan fungsi organ sistem ekskresi.

Tahap observasi dilaksanakan saat pembelajaran berlangsung. Adapun hasil observasi yaitu: (1) Saat diskusi berlangsung masih ada beberapa peserta didik yang tidak serius dan mengganggu temannya. Guru hanya menegur seadanya 
karena terlalu fokus dalam memberikan bimbingan kepada kelompok lain; (2) Guru kurang dalam manajemen waktu sehingga menyebabkan satu kelompok tidak dapat melakukan presentasi; (3) Guru terlalu fokus memperhatikan kelompok tertentu dan kurang memperhatikan kelompok yang lainnya; dan (4) Peserta didik masih sedikit yang bertanya dan menjawab pertanyaan.

Tahap terakhir yaitu refleksi, adapun hasil refleksi pada siklus I yaitu: (1) Guru harus lebih tegas menegur peserta didik untuk serius ketika diskusi dan tidak mengganggu temannya; (2) Guru perlu memperhatikan manajemen waktu, sehingga kegiatan pembelajaran terlaksana sesuai dengan rencana pembelajaran yang telah dibuat; (3) Guru harus memperhatikan semua kelompok saat kegiatan diskusi berlangsung dan memberikan bimbingan untuk tiap kelompok; (4) Guru harus melibatkan peserta didik untuk aktif mengajukan pertanyaan dan menjawab pertanyaan. Guru akan memberikan kesempatan peserta didik untuk mengajukan pertanyaan dan menunjuk peserta didik yang terlihat pasif menjawab pertanyaan.

Proses pembelajaran telah terlaksana dengan kategori baik dan hasil belajar peserta didik secara klasikal telah mencapai indikator keberhasilan. Namun ada beberapa indikator aktivitas belajar peserta didik yang masih rendah persentasenya sehingga diperlukan perbaikan pada siklus selanjutnya.

\section{Siklus II}

Tahap perencanaan pada siklus II peneliti menyiapkan instrumen penelitian seperti pada siklus I. Kemudian ditambahkan perbaikan berdasarkan hasil refleksi pada siklus I. Tahap tindakan penelitian siklus II dilakukan pada Rabu, 8 Mei 2019 pukul 07.00-08.20 WIB dengan alokasi waktu 2x40 menit. Materi yang diajarkan tentang gangguan pada sistem ekskresi dan cara menjaga kesehatan organ sistem ekskresi. Tahap observasi diperoleh hasil yaitu: (1) Kegiatan pembelajaran pada siklus II telah dilakukan guru secara teliti sehingga semua tahapan pembelajaran telah dilakukan sesuai dengan RPP; (2) Saat kegiatan diskusi berlangsung peserta didik sudah serius berdiskusi bersama kelompoknya. Hal ini menyebabkan kerja sama kelompok dalam diskusi telah lebih baik terlihat dari semua kelompok telah berhasil menyelesaikan pengerjaan LKPD tepat waktu; 
(3) Guru memperhatikan semua kelompok saat berdiskusi sehingga tiap kelompok mendapatkan bimbingan dari guru; dan (4) Peserta didik sudah lebih banyak yang bertanya dan menjawab pertanyaan.

Hasil refleksi pada siklus II yaitu: (1) Guru sudah teliti melaksanakan setiap tahapan pembelajaran sesuai dengan RPP; (2) Kegiatan diskusi diselesaikan tepat waktu dan peserta didik sudah bekerja sama dengan baik bersama kelompoknya; (3) Guru telah memberikan bimbingan kepada tiap kelompok; (4) Peserta didik sudah lebih banyak yang mengajukan pertanyaan dan menjawab pertanyaan, serta bersemangat selama proses pembelajaran. Aktivitas belajar yang lainnya seperti memperhatikan guru menjelaskan, membaca, mendengarkan, berdiskusi, mencatat, dan megerjakan latihan telah terlihat pada semua peserta didik. Penelitian tindakan kelas ini berhenti sampai siklus II dikarenakan pada siklus II telah terjadi peningkatan proses pembelajaran, aktivitas belajar peserta didik, dah hasil belajar.

\section{Peningkatan aktivitas belajar peserta didik}

Berdasarkan hasil penelitian diketahui bahwa persentase aktivitas belajar peserta didik menggunakan model pembelajaran SAVI berbantuan media flashcard mengalami peningkatan dari siklus I ke siklus II sebesar 13,64\%. Aktivitas belajar peserta didik mengalami peningkatan dengan menggunakan model pembelajaran SAVI (Armawati, dkk., 2015). Aktivitas belajar peserta didik mengalami peningkatan dari siklus I ke siklus II sebesar 23,7\% dengan menggunakan media flashcard. Peningkatan aktivitas belajar secara klasikal ini sejalan dengan meningkatnya persentase tiap indikator aktivitas belajar (Febriyanto dan Yanto, 2019).

Indikator pertama yaitu memerhatikan guru menjelaskan. Aktivitas memerhatikan guru saat menjelaskan materi pada siklus I dan II mencapai $100 \%$. Hal ini dikarenakan pada saat guru ingin menyampaikan materi kepada peserta didik, guru selalu mengondisikan peserta didik untuk memperhatikan guru di depan kelas. Adapun karakteristik SAVI pada aktivitas memperhatikan guru menjelaskan yaitu belajar visual. Belajar visual menarik bagi peserta didik karena 
tidak rumit dalam proses pembelajarannya (Ibrahim dan Hussein, 2015). Belajar visual diantaranya dapat dilakukan dengan menggunakan media gambar seperti media flashcard.

Indikator kedua yaitu membaca. Aktivitas membaca diamati pada saat peserta didik mengerjakan LKPD dan media flashcard. Pada siklus I dan II persentase aktivitas membaca mencapai 100\%. Supaya peserta didik tidak mengalami kebosanan, maka peserta didik harus memberikan perhatian terhadap bahan bacaannya sehingga minat tinggi (Triatma, 2016). Tingginya minat membaca dikarenakan adanya media flashcard yang memiliki gambar yang menarik dan berupa poin-poin penting penjelasan materi ekskresi. Media flashcard mengombinasikan anatara gambar dan kata yang memuat keterangan gambar tersebut pada setiap kartu sehingga memberikan kemudahan bagi peserta didik untuk mengingat dan mengenali konsep (Susilana dan Riyana, 2009).

Indikator ketiga yaitu mengajukan pertanyaan. Persentase peserta didik yang mengajukan pertanyaan pada siklus I hanya sebesar 36,36\%. Peserta didik yang mengajukan pertanyaan cenderung orang yang sama. Sedangkan peserta didik yang lain hanya diam ketika diminta untuk bertanya. Hal tersebut disebabkan peserta didik kurang memahami materi yang dipelajari dan kurang percaya diri. Rasa percaya diri terhadap kemampuan diri membuat peserta didik enggan bertanya. Adapun upaya guru untuk meningkatkan jumlah peserta didik yang bertanya adalah memberikan penekanan materi dan peserta didik diminta untuk saling bekerja sama. Guru meminta peserta didik yang sudah bertanya untuk membantu temannya yang belum bertanya sehingga peserta didik mendapatkan kepercayaan diri untuk bertanya. Rasa percaya diri yang kuat pada peserta didik akan membuat mereka menganggap kegagalan sebagai penyemangat untuk terus belajar (Pritama, 2015). Hal ini menyebabkan persentase mengajukan pertanyaan meningkat pada siklus II menjadi 63,64\%.

Indikator keempat yaitu menjawab pertanyaan. Persentase menjawab pertanyaan pada siklus I hanya sebesar $45,45 \%$ dikarenakan hanya beberapa peserta didik yang menjawab pertanyaan dan cenderung orang yang sama. Selain itu, saat peserta didik mengajukan pertanyaan guru langsung memebrikan 
penjelasan tanpa memberikan kesempatan kepada peserta didik yang lain untuk menjawab. Adapun perbaikan yang dilakukan guru pada siklus II yaitu peserta didik diberikan kesempatan untuk menjawab terlebih dahulu. Kemudian peserta didik yang sudah menjawab pertanyaan diminta untuk membantu teman kelompoknya agar berani menjawab pertanyaan dengan mencari jawaban pada media flashcard. Sehingga pada siklus II persentase menjawab pertanyaan meningkat menjadi $72,73 \%$.

Indikator kelima yaitu mendengarkan. Mendengarkan merupakan suatu proses aktif seseorang dalam memahami apa yang disampaikan dengan memberikan perhatian kepada si pembicara (Aminah, 2018). Peserta didik diharapkan mendengarkan ketika guru menjelaskan materi sehingga dapat menyerap materi yang dipelajari dan terlibat aktif dalam mengajukan pertanyaan atau menjawab pertanyaan. Pada siklus I aktivitas mendengarkan memperoleh persentase sebesar 90,91\%. Upaya yang dilakukan agar semua peserta didik mendengarkan saat guru menjelaskan adalah menegur peserta didik dengan tegas. Sehingga pada siklus II aktivitas mendengarkan meningkat menjadi $100 \%$. Selama guru menjelaskan materi, peserta didik diharapkan memberikan umpan balik dari apa yang didengarnya seperti mengajukan pertanyaan dan menjawab pertanyaan. Memberikan perhatian kepada pembicara, pendengar dapat menyerap dan memahami informasi yang diberikan dan memberi tanggapan atau pertanyaan (Martoredjo, 2014). Semakin aktif seseorang mendengarkan informasi maka semakin besar rasa ingin tahu untuk memperoleh pemahaman dengan cara bertanya (Sari, 2016).

Indikator keenam yaitu berdikusi. Pada siklus I persentase berdiskusi sebesar 81,82\%. Masih terdapat beberapa peserta didik yang mengganggu temannya dan tidak serius bekerja sama dengan kelompoknya. Upaya perbaikan yang dilakukan guru adalah memberikan teguran agar lebih serius dalam belajar dan akan memberikan pengurangan nilai jika mengganggu temannya. Sehingga terlihat di siklus II, terjadi peningkatan persentase berdiskusi menjadi $100 \%$. Pembelajaran dengan berdiskusi dapat meningkatkan pengetahuan peserta didik. Melalui diskusi peserta didik dituntut untuk memberikan pendapat terhadap suatu 
permasalahan sehingga mampu merangsang kreativitas dan melatih komunikasi dengan orang lain (Sitorus, 2017).

Indikator ketujuh yaitu mencatat. Selama guru menjelaskan, peserta didik diwajibkan mencatat poin-poin penting terkait materi pelajaran. Peserta didik juga diharapkan mencatat hasil diskusi. Pada kedua siklus semua peserta didik mencatat materi dan hasil diskusi sehingga persentase aktivitas mencatat mencapai $100 \%$. Mencatat merupakan cara agar peserta didik mudah mengingat dan memahami materi. Kapasitas memori yang dimiliki manusia terbatas sehingga peserta didik diharuskan selalu mencatat informasi yang didapat saat mengikuti proses pembelajaran (Dewi dan Indrawati, 2014). Selain itu, meningkatnya persentase mencatat dikarenakan adanya media flashcard yang menarik antusias peserta didik sehingga lebih semangat dalam mengikuti pembelajaran.

Indikator kedelapan yaitu mengerjakan latihan. Peserta didik mengerjakan latihan pada saat guru memberikan soal evaluasi pada akhir pembelajaran. Semua peserta didik mengerjakan latihannya sehingga pada siklus I dan II persentase mengerjakan latihan mencapai $100 \%$. Model pembelajaran SAVI menekankan pada karakteristik intelektual yang menstimulasi peserta didik dalam berpikir secara kritis untuk pemecahan suatu masalah pada soal evaluasi. Penggabungan karakteristik somatik, auditori, dan visual akan membentuk intelektualitas peserta didik lebih kritis serta lebih melekat dalam ingatan peserta didik.

Indikator kesembilan yaitu bersemangat. Bersemangat termasuk dalam aktivitas emosional. Peserta didik yang bersemangat akan menaruh perhatian yang tinggi terhadap proses pembelajaran. Dengan perhatian, peserta didik akan memusatkan segala pikiran dan perasannya ke sesuatu yang menjadi tumpuan perhatiannya (Fiteriani, 2015). Adanya perhatian yang tinggi maka peserta didik akan percaya diri saat belajar sehingga tidak merasa ragu untuk mengungkapkan pendapatnya. Aktivitas bersemangat diukur dengan mengamati kepercayaan diri yang kuat dari peserta didik dalam menanggapi pertanyaan dari guru atau menjawab pertanyaan. Pada siklus I persentase bersemangat cukup rendah yaitu sebesar 59,09\%. Hal ini disebabkan peserta didik kurang termotivasi mengikuti pembelajaran, kurang percaya diri untuk bertanya dan menjawab. Setelah 
dilakukan upaya perbaikan pada aktivitas bertanya dan menjawab, persentase aktivitas bersemangat pada siklus II meningkat menjadi 86,36\%.

\section{Peningkatan hasil belajar peserta didik}

Hasil belajar berdasarkan jumlah peserta didik yang tuntas pada siklus I sebanyak 18 orang dengan persentase sebesar $81,82 \%$, mengalami peningkatan pada siklus II menjadi 21 orang dengan persentase 95,45\%. Berdasarkan hal tersebut, diketahui adanya peningkatan hasil belajar dari siklus I ke siklus II sebesar 13,63\%. Hasil penelitian terdahulu menunjukkan bahwa model pembelajaran SAVI berhasil meningkatkan hasil belajar peserta didik (Wardani, 2017) dan media flashcard dapat meningkatkan hasil belajar peserta didik (Febriyanto dan Yanto, 2019).

Meningkatnya hasil belajar peserta didik menggunakan model pembelajaran SAVI berbantuan media flashcard dikarenakan peserta didik memusatkan perhatiannya secara penuh terhadap pembelajaran yang berlangsung sehingga hasil belajar dapat tercapai dengan baik. Melalui penggunaan model pembelajaran SAVI dalam proses pembelajaran, peserta didik dapat memperoleh pengetahuan yang diajarkan dengan berbagai cara, sehingga hasil belajar akan mengalami peningkatan (Rusman, 2016).

\section{SIMPULAN}

Pembelajaran menggunakan model SAVI berbantuan media flashcard pada siklus I terlaksana baik dengan persentase keterlaksanaan 92,31\% dan pada siklus II $100 \%$. Hal ini menunjukkan adanya peningkatan dalam keterlaksanaan pembelajaran dari siklus I ke siklus II sebesar 7,69\%. Aktivitas belajar peserta didik pada siklus I sebesar $77,27 \%$ dan pada siklus II 90,91\%. Hal ini menunjukkan adanya peningkatan aktivitas belajar peserta didik sebesar 13,64\%. Hasil belajar peserta didik pada siklus I peserta didik sebesar $81,82 \%$ dan pada siklus II 95,45\%. Hal ini menunjukkan adanya peningkatan hasil belajar peserta didik sebesar $13,63 \%$. 


\section{DAFTAR PUSTAKA}

Aminah, S. 2018. Pentingnya Mengembangkan Ketrampilan Mendengarkan Efektif dalam Konseling. Jurnal Educatio, 4(2): 2477-0302.

Amu, T. D. N., Jamaludin, \& Hasdin. 2014. Meningkatkan Perhatian Siswa Kelas V SDN 2 Salakan pada Mata Pelajaran PKn melalui Metode Diskusi. Jurnal Kreatif Tadulako Online, 2(3): 2354-614X.

Arikunto. 2013. Prosedur Penelitian Suatu Pendekatan Praktek. Jakarta: PT. Rineka Cipta.

Arsyad, A. 2016. Media Pembelajaran. Jakarta: Raja Grafindo Persada.

Armawati, Samad A., \& Azis A. 2015. Penerapan Model Pembelajaran SAVI (Somatik, Auditori, Visual dan Intelektual) dapat Meningkatkan Hasil Belajar Fisika pada Peserta Didik Kelas VII.A SMP Aisyiyah Sungguminasa. Jurnal Pendidikan Fisika, 3(2): 116-122.

Chozaipah. 2018. Peran dan Partisipasi Siswa dalam Pembelajaran terhadap Prestasi Belajar Akuntasi di SMKN 1 Dumai Provinsi Riau. Jurnal Serambi PTK, 5(1): 2355-9535.

Dewi, I. \& Indrawati, K. R. 2014. Perilaku Mecatat dan Kemampuan Memori pada Proses Belajar. Jurnal Psikologi Udayana, 1(2): 241-250.

Febriyanto, B. \& Yanto, A. 2019. Penggunaan Media Flashcard untuk Meningkatkan Hasil Belajar Siswa Sekolah Dasar. Jurnal Komunikasi Pendidikan, 3(2): 108-116.

Fiteriani, I. 2015. Membudayakan Iklim Semangat Belajar pada Siswa Sekolah Dasar. Jurnal Terampil: Pendidikan dan Pembelajaran Dasar, 2(1): 115125.

Hasnah, Y. \& Dewi, R. S. 2018. Peningkatan Prestasi Belajar Mahasiswa melalui Pendekatan SAVI pada Mata Kuliah. Curriculum and Material Development. Jurnal Tarbiyah, 25(2): 2597-4270.

Ibrahim, R. H. \& Hussein, D. A. 2015. Assessment of Visual, Auditory, and Kinesthetic Learning Style Among Undergraduate Nursing Students. International Journal of Advanced Nursing Studies, 5(1): 1-4.

Jauhari, M. I. 2018. Peran Media Pembelajaran dalam Pendidikan Islam. Jurnal Piwulang, 1(1): 54-67.

Martoredjo, N. T. 2014. Keterampilan Mendengarkan secara Aktif dalam Komunikasi Interpersonal. HUMANIORA, 5(1): 501-509.

Ngalimun. 2016. Strategi dan Model Pembelajaran. Yogyakarta: Aswaja Pressindo.

Novitasari, D. 2017. Penerapan Pendekatan SAVI untuk Meningkatkan Aktivitas Matematik. Prima, 6(1): 33-45.

Pritama, D. 2015. Studi tentang Upaya Guru dalam Meningkatkan Kepercayaan Diri Siswa SD Negeri 1 Pengasih. Jurnal Pendidikan Guru Sekolah Dasar, 4(12): 1-10.

Puspitasari, A., Hermahayu, \& Purnanto, A. W. 2018. Pengaruh Model Pembelajaran SAVI dengan Media Hide and Seek terhadap Hasil Belajar IPA. Edukasi: Jurnal Pendidikan, 10(2): 137-148.

Rusman. 2016. Model-Model Pembelajaran. Jakarta: Raja Grafindo Persada. 
Sari, A. W. 2016. Pentingnya Ketrampilan Mendengar dalam Menciptakan Komunikasi yang Efektif. Jurnal Edu Tech, 2(1): 2442-7063.

Sitorus, E. 2017. Peningkatan Keterampilan Diskusi Siswa Kelas VII SMP melalui Model Pembelajaran Two Stay Two Stray. SEJ, 7(4): 506-549.

Susilana, R. \& Riyana, C. 2009. Media Pembelajaran. Bandung: CV Wacana.

Triatma, I. N. 2016. Minat Baca pada Siswa Kelas VI Sekolah Dasar Negeri Delegan 2 Prambanan Sleman Yogyakarta. E-Journal Prodi Teknologi Pendidikan, 5(6): 166-178.

Wardani, F. P. 2017. Penerapan Model Pembelajaran SAVI untuk Meningkatkan Hasil Belajar IPA Siswa Kelas V Sekolah Dasar. Jurnal PANCAR, 1(2): 5-8.

Wibowo, N. 2016. Upaya Peningkatan Keaktifan Siswa melalui Pembelajaran Berdasarkan Gaya Belajar di SMK Negeri 1 Saptosari. Jurnal Electronixs, Informatics, and Vocational Education (ELINVO), 1(2): 128-139. 